\title{
KEBIJAKAN PENANAMAN MODAL ASING (PMA) DAN DAMPAK KEDAULATAN BANGSA
}

\author{
Sirwanto \\ Institut Agama Islam Negeri (IAIN) Bengkulu \\ Jalan Raden Fatah, Kota Bengkulu \\ Email: Sirwanto@gmail.co.id
}

\begin{abstract}
Indonesia in carrying out development requires a very large capital, because of the vast territory and a very large population. But in fact Indonesia has the potential of natural resources (SDA) which is very large too, if the potence can be managed solely for the interests of the people as mandated in article 33 of the 1945 Constitution of the Republic of Indonesia. To accelerate the management of these natural resources, the government need investment both from within the country, and from foreign investment (PMA). Because domestic investment is relatively small compared to the cost of managing natural resources, while this nation must catch up with other nations, PMA is a very possible alternative to this, even though it is very risky for foreign intervention to sovereignty of the country. For this reason, the government must make clear and impartial regulations, consistent with these regulations and have a good political will, so that problems can be overcome and the sovereignty of the nation and state is maintained, so that this nation will advance equally with the nations other majalis nation.
\end{abstract}

Keywords: PMA, Government, Sovereignty and investment

\begin{abstract}
Abstrak: Indonesia dalam melaksanaan pembangunan membutuhkan modal yang sangat besar, karena luas wilayah yang sangat luas dan penduduknya yang sangat besar. Namun sesungguhnya Indonesia memiliki potensi sumber daya alam (SDA) yang sangat besar pula, jika potensi tersebut bisa dikelola semata-mata untuk kepentingan rakyat sebagaimana diamanahkan dalam pasal 33 Undang-Undang Dasar Negara Republik Indonesia Tahun 1945. Untuk mempercepat pengelolaan sumber daya alam tersebut, pemerintah membutuhkan investasi baik dari dalam negeri, maupun dari investasi asing (PMA). Kaena investasi dalam negeri relatif kecil jika dibandingkan kebutuhan biaya pengelolaan sumber daya alam tersebut, sementara bangsa ini harus mengejar ketertinggalannya dari bangsa lain, maka PMA merupakan alternatif yang sangat memungkinkan untuk hal itu, meskipun sangat riskan terjadinya intervensi asing terhadap kedaulatan negara. Untuk itu pemerintah harus membuat regulasi yang jelas dan memihak kepada kepentingan bangsa, konsisten dengan regulasi tersebut dan memiliki political will (kemauan politik) yang baik, sehingga permasalahan bisa teratasi dan kedaulatan bangsa dan negara tetap terjaga, sehingga bangsa ini akan maju sederajat dengan bangsa-bangsa maju lainnya.
\end{abstract}

Kata Kunci: PMA, Pemerintah, Kedaulatan dan investasi; 

AL-IMARAH: Jurnal Pemerintahan dan Politik Islam Vol. 5, No. 1, 2020

\section{Pendahuluan}

Setiap negara yang sedang berkembang termasuk Indonesia, sudah pasti membutuhkan investasi yang besar untuk menyelenggarakan pemerintahan negara, karena tugas negara yang sangat besar sebagaimana diamanahkan dalam pembukaan Undang Undang Dasar Negara Republik Indonesia Tahun 1945, yaitu, "melindungi segenap bangsa dan seluruh tumpah darah Indonesia, dan memajukan kesejahteraan umum, mencerdaskan kehidupan bangsa dan ikut melaksanakan ketertiban dunia yang berdasarkan kemerdekaan, perdamaian abadi dan keadilan sosial". amanah tersebut mustahil bisa tertunaikan dengan baik, jika negara tidak memiliki modal.

Untuk melindungi segenap bangsa Indonesia dan seluruh tumpah darah Indonesia, dibutuhkan pasukan yang kuat dan alat-alat persenjataan yang modern dan bersaing, transportasi yang modern, SDM yang siap dan besar. Memajukan kesejahteraan umum dengan menyediakan kebutuhan sandang, pangan dan papan, layanan kesehatan, layanan pendidikan dan lapangan kerja yang kompetitif. Mencerdaskan kehidupan bangsa berarti negara harus menyediakan lembaga pendidikan yang berkualitas dan SDM yang handal dan biaya riset serta penunjang pendidikan lainnya. Semua membutuhkan dana yang sangat besar.

Pemerintah selaku pengemban tugas berat tersebut tentu tidak memiliki cukup dana untuk membiayai tugas tersebut, oleh karena itu diperlukan partisipasi rakyat untuk turut berinvestasi dalam pembangunan dan juga membuka peluang penanaman modal asing agar SDA yang besar itu dikelola dan menghasilkan dana untuk kebutuhan pembangunan.

\section{Pemerintah telah menetapkan} kebijakan bidang-bidang yang memerlukan penanaman modal dengan berbagai regulasi dan peraturan serta menentukan besarnya modal dan perbandingan antara modal nasional dengan modal asing. Hal ini dilakukan untuk menjamin agar penanaman modal asing dapat diarahkan pada satu tujuan yang hendak dicapai, karena seringkali suatu negara tidak dapat menentukan politik ekonominya secara bebas, akibat adanya intervensi dari pemerintah negara pemilik modal asing.

Kebijakan mengundang modal asing, adalah untuk tujuan meningkatkan poteni ekspor dan substitusi impor, sehingga Indonesia mampu meningkatkan penghasilan dan menghemat devisa. Untuk itu usaha di bidang ini diberi prioritas dan fasilitas. Alasan yang lain yaitu agar terjadi alih teknologi yang dapat mempercepat laju pertumbuhan ekonomi dan pembangunan nasional Indonesia.

Mengingat pentingnya penanaman modal asing dalam pembangunan nasional, berbagai strategi untuk mngundang investor asing telah dilakukan. Hal ini didukung oleh 
Sirwanto Kebijakan Penanaman Modal Asing (Pma) Dan Dampak Kedaulatan Bangsa

arah kebijakan ekonomi dalam Tap MPRRI No. IV/MPR/1999, di mana salah satu kebijakan ekonomi nasional adalah mengoptimalkan peranan pemerintah dalam mengoreksi ketidak sempurnaan pasar dengan berbagai kemudahan perijinan investasi, menjamin kepastian hukum berinvestasi, serta menghilangkan seluruh hambatan yang mengganggu mekanisme pasar, melalui regulasi, layanan publik, subsidi dan insentif, yang dilaksanakan secara transparan dan diatur dengan undang-undang.

Sejak kebijakan pemerintah memberlakukan UU N0. 11 tahun 1967 tentang Pertambangan dan setelah dishkannya UU No. 1 Tahun 1967 tentang PMA, kontrak karya ditandatangani oleh pemerintah Indonesia dengan PT. Freeport Indonesia selama 30 tahun, sebagaimana yang didasarkan pada pasal 8 UU No. 1 Tahun 1967, “ Penanaman Modal Asing di bidang pertambangan didasarkan pada satu kerja sama dengan pemerintah melalui kontrak karya atau bentuk lain sesuai dengan perundangan, dengan luas wilayah kurang lebih $10 \mathrm{~km}^{2}$, kemudian disusul dengan kontrak karya dengan perusahaan asing yang lain di berbagai bidang. ${ }^{1}$

Dengan hadirnya investasi ini, maka seharusnya dalam waktu 30 tahun, (19671997), Indonesia telah menguasai mayoritas saham PT Freeport Indonesia, baik benda, teknologi maupun SDM, karena ada proses divestasi sebesar 51\% dari PT Freeport, sebagaimana aturan yang dibuat dan disepakati bersama. Meski dalam pelaksanaan pemerintah hanya menuntut $30 \%$, disinyalir hal ini karena adanya tekanan internasional ${ }^{2}$.

Dari pemaparan di atas, disinyalir ada wanprestasi dari kontrak karya Freeport Indonesia dengan pemerintah Indonesia, untuk itu perlu dikaji secara ilmiah dengan judul "Kebijakan Penanaman Modal Asing di Indonesia dan Dampaknya terhadap Kedaulatan Bangsa".

\section{A. Rumusan Masalah}

Dari pemaparan diatas, maka penulis merumuskan masalah sebagai berikut :

1. Adakah keuntungan dan kerugian negara?

2. Apakah ada kesalahan dari regulasi ?

3. Apakah ada kesalahan implementasi dari regulasi ?

4. Apakah ada intervensi asing yang mempengaruhi kedaulatan bangsa dalam kebijakan PMA ?

\section{B. Tujuan Dan Manfaat Kajian}

Tujuan kajian ini adalah :

1. Untuk mengetahui sejauh mana keuntungan dan kerugian negara dalam kebijakan PMA, khususnya

\footnotetext{
${ }^{1}$ Rahadian, isat@Xperia X8
} 
kontrak karya antara Pemerintah Indonesia dengan Freeport Indonesia.

2. Untuk mengetahui adakah kesalahan regulasi atau implementasi regulasinya ?

3. Untuk mengidentifikasi sejauh mana PMA mengganggu kedaulatan negara

Adapun manfaatnya, secara teoritis adalah untuk menelaah efektifitas penyelenggaraan pemerintah Indonesia dan dampak sosial ekonomi bagi masyarakat dalam konteks PMA, sedangkan secara praksis agar mendapat data sebagai bahan evaluasi bagi pemerintah dan mengetahui posisioning Indonesia di mata asing. Sedangkan bagi ilmu pengetahuan memberikan data sekunder bagi pengkajian PMA sebagai landasan untuk pembentukan regulasi ke depan.

\section{Pembahasan}

1. Landasan Teori

Definisi penanaman modal menurut UU No. 25 tahun 2007, tentang penanaman modal adalah, "segala bentuk penanaman modal baik penanaman modal domestik maupun asing, untuk melakukan usaha di wilayah Republik Indonesia". Kamaruddin Ahmad memberi definisi," menempatkan uang atau dana dengan harapan untuk memperoleh tambahan atau keuntungan tertentu atas uang tersebut". Sedangkan dalam Ensiklopedi Indonesia, investasi adalah "penanaman modal dalam proses produksi, dengan demikian cadangan modal barang diperbesar sejauh tidak ada modal barang yang harus diganti"3.

Namun demikian karena Indonesia sebagai sebuah negara bukan ruang kosong tanpa aturan, akan tetapi pembentukan negara memiliki tujuan yang jelas sebagaimana termaktub dalam pembukaan UUDRI 1945, maka pemerintah yang diamanahi untuk menjalankan fungsi negara tersebut membuat regulasi sehingga apapun kegiatan yang dilakukan di Indonesia tidak menyimpang dari orientasi dibentuknya negara, termasuk dalam investasi.

\section{a. Teori Welfare State}

Dalam pembukaan Undang-Undang Dasar Republik Indoneia tahun 1945, bahwa didirikannya negara Indonesia ini dengan tujuan yang jelas, yaitu melindungi segenap bangsa dan seluruh tumpah darah indonesia memajukan kesejahteraan umum, mencerdaskan kehidupan bangsa dan ikut melaksanakan ketertiban dunia yang berdasarkan kemerdekaan, perdamaian abadi dan keadilan sosial. dengan demikian maka Indonesia menganut paham walfare state (negara kesejahteraan), dimana jaminan kesejahteraan rakyat dan keadilan sosial menjadi kewajiban negara untuk memenuhinya ${ }^{4}$. Begitu juga dalam pandangan Jimly Asshiddiqie yang mengatakan bahwa “...

\footnotetext{
${ }^{3}$ Salim HS, h. 108

${ }^{4}$ Alfitri, Ideologi Walfare State Dalam Dasar Negara Indonesia; Jurnal Konstitusi ; Volume 9, No 3,
} September 2012, h. 449. 
Indonesia adalah negara kesejahteraan (welfare state) yang mengidealkan sifat intervensionisme negara dalam dinamika perekonomian masyarakat, semata-mata untuk kepentingan kesejahteraan masyarakat" .

Kemudian tujuan negara itu dibrackdown secara konseptual dalam batang tubuh UUD 1945 pasal 33 ayat 1 Perekonomian disusun sebagai usaha bersama berdasar atas azas kekeluargaan, ayat 2 Cabang-cabang produksi yang penting bagi negara dan menguasai hajat hidup orang banyak, dikuasai oleh negara. Ayat 3 Bumi dan air dan kekayaan alam yang terkandung di dalamnya dikuasai oleh negara, dan dipergunakan untuk sebesar-besarnya kemakmuran rakyat. MK dalam putusan pengujian UU yang berkaitan dengan sumber daya alam (natural resources) memiliki kesatuan pandangan mengenai pengertian frasa "dikuasai oleh negara" dalam Pasal 33 UUD 1945. MK menolak pandangan bahwa penguasaan oleh negara berarti kepemilikan dalam konsep hukum perdata atau hanya sebatas pengaturan. Penguasaan oleh negara haruslah diartikan sebagai tindakan untuk merumuskan kebijakan (beleid), melakukan tindakan pengurusan (bestuur sdaad), melakukan pengaturan (regelendaad), melakukan pengelolaan (beheersdaad), dan melakukan

pengawasan

5 Basariyadi, Pergulatan Paham Negara Kesejahteraan. Jurnal Hukum Ius Quia Lustum Volume 23 No. 4 Oktober 2016, h. 438. (toezichthoudendaad)" Kewenangan negara untuk melakukan tindakan-tindakan tersebut adalah kumulatif dan tidak boleh direduksi. Tujuan negara untuk menguasai cabang produksi yang penting adalah demi ketersediaan yang cukup, distribusi yang merata, dan terjangkaunya harga bagi banyak orang $^{7}$.

Begitupun tafsiran MK terkait dengan Pasal 34 UUDRI Tahun 1945 tatkala mengadili Judicial Review UU No. 40 tahun 2004 tentang Sistem Jaminan Sosial Nasional, bahwa penegasan terhadap negara kesejahteraan yang didirikan oleh para pendiri negara tersebut. Dalam hal ini, keadilan sosial tidak bisa dipisahkan dengan kesejahteraan, karena keduanya saling mempengaruhi.

Dari teori ini maka ketika pemerintah melakukan kontrak karya dengan perusahaan asing khususnya dibidang pertambangan dan eksplorasi sumber daya alam, maka orientasinya adalah bagaimana PMA tersebut melahirkan kesejahteraan masyarakat, maka melakukan PMA dengan tujuan semata-mata kepentingan politik praktis (politic minded),

${ }^{6}$ Putusan Mahkamah Konstitusi Nomor 001021-022/PUU-I/2003 tentang Pengujian UU Nomor 20 Tahun 2002 tentang Ketenagalistrikan terhadap UUD 1945, h. 334; lihat juga Putusan Mahkamah Konstitusi Nomor 002/PUU-I/2003 tentang Pengujian UU Nomor 22 Tahun 2001 Minyak dan Gas Bumi, hlm. 208; dan lihat Putusan Mahkamah Konstitusi Nomor 058-059060-063/PUU-II/2004 dan Nomor 008/PUU-III/2005 tentang Pengujian UU Nomor 7 Tahun 2004 tentang Sumber daya Air h. 498-499.

7 Putusan Mahkamah Konstitusi Nomor 002/PUU-I/2003 tentang Pengujian UU Nomor 22 Tahun 2001 Minyak dan Gas Bumi, h. 330. 
AL-IMARAH: Jurnal Pemerintahan dan Politik Islam Vol. 5, No. 1, 2020

bertentangan dengan hukum, apalagi jika menyebabkan terancamnya kedaulatan bangsa.

\section{b. Teori Neokolastik}

Kaplinsky berpendapat bahwa investasi asing diperlukan dalam mengembangkan perkembangan dan pembangunan suatu negara. Pendapat ini didukung oleh Adi Harsono, John W. Head, William E. Fennel, Joshef W. Tyler dan Eric M. Burt, yang menjelaskan keuntungan investasi Asing itu meliputi : Modal kerja, keahlian, devisa, tidak melahirkan hutang baru, lowongan kerja, meningkatkan ekspor, mendapat pajak tambahan dan sebagainya. namun juga harus tetap diwaspadai terhadap efek negatif dari PMA ini, diantaranya adalah: kerusakan lingkungan, determinasi terhadap perusahaan lokal, dan bahkan bisa mengancam kedaulatan suatu negara berupa dominasi terhadap kebijakan negara. Untuk itu Sornarajah telah mengembangkan teori jalan tengah (middle path theory) diantara polarisasi teori klasik yang menyatakan bahwa PMA akan memberi manfaat dan teori ketergantungan yang menyatakan bahwa PMA sifatnya membahayakan ${ }^{8}$.

Kedua teori yang bertentangan tersebut perlu penanganan konflik yang baik. Konflik, menurut Dean G. Pruitt danJeffrey Z. Rubbin adalah persepsi mengenai perbedaan kepentingan atau aspirasi pihak-pihak yang bersengketa tidak bisa dicapai secara serentak atau tidak ada kesepakatan kepentingan antara para pihak dan akhirnya terjadi pertentangan, perselisihan dan percekcokan berkaitan dengan sesuatu yang bernilai, baik uang ataupun benda.

Dalam implementasi PMA di Indonesia konflik terjadi antara PT. Newmont Nusa Tenggara Barat dengan masyarakat di desa Elang Edo kecamatan Ropang Timur Kabupaten Sumbawa. Dalam konflik itu rakyat berpendapat bahwa tanah di mana PT Newmont Nusa Tenggara melakukan eksplorasi itu merupakan tanah leluhur mereka yang telah ditinggalkan selama 75 tahun, sehingga rakyat menuntut gant rugi. Sedangkan persepsi PT. Newmont bahwa eksplorasi dilakukan di tegah hutan yang dikuasai oleh negara. Oleh karena itu perusahaan tidak perlu membayar ganti rugi. Karena perusahaan telah menandatangani kontrak karya dengan pemerintah ${ }^{9}$.

Kedua belah pihak memiliki persepsi yang berbeda terhadap kepentingan yang sama, yaitu ksplorasi tambang di hutanNusa Tenggara. Untuk menyelesaikan konflik tersebut dalam kontrak karya PT Newmont dengan pemerintah Indonesia telah sepakat menyelesaikan konflik dengan dua cara, sebagaimana termaktub dalam pasal 21 kontrak karya yaitu konsiliasi dan arbitasi. Konsiliasi adalah pertemuan penyelesaian sengketa antara pihak-pihak yang bersengketa,

\footnotetext{
${ }^{9}$ Salim HS, h. 103-105.
} 
sedangkan arbitasi adalah pertemuan antara pihak-pihak yang bersengketa melalui mediasi oleh pihak ketiga yang dipilih oleh masingmasing pihak sebagai mediator.

Disamping konflik dengan rakyat, PT. Newmont Nusa Tenggara juga konflik dengan pemerintah terkait dengan divestasi (pengalihan investasi dari PT Newmont Nusa Tenggara kepada Pemerintah Propinsi Nusa Tenggara Barat) sebesar $30 \%$ sebagaimana telah disepakati dalam kontrak karya, tetapi PT Newmont Nusa Tenggara tidak memenuhi kesepakatan itu. Negosiasi yang dilakukan mengalami deadlock (jalan buntu) dan diambil langkah penyelesaian konflik melalui arbitasi international ${ }^{10}$.

Sisi negatif lainnya dalam PMA dan ini yang terpenting adalah upaya intervensi pihak PMA kepada pemerintah, yang melibatkan kekuasaan internasional yang menyangkut masalah kedaulatan negara. Seperti yag diberitakan majalah Forum Keadilan ${ }^{11}$.

"Kemudian enam tahun menjelng berakhirnya kontrak karya freeport, tepatnya tahun 1991, perusahaan itu meminta renegosiasi kontrak dengan pemerintah Indonesia yang masih ditandatangani oleh Soeharto. Meskipun ada penyertaan modal di situ, diantaranya ada saham Bob Hasan dan

\footnotetext{
${ }^{10}$ Salim HS. h. 105.

${ }^{11}$ Majalah Forum Keadilan Edisi 06/27 Mei-2 Juni 2013 .
}

Abdul Latief, namun mayoritas saham dikuasai oleh freeport Mac Moran.

Ketika rezim Soeharto tumbang, mulai membesarlah tekanan-tekanan terhadap freeport. Nah, setiap ada tekanan, kelihatan betul mulai ada back up dari pemerintah AS, apakah melalui kedutaan AS atau melalui senator-senatornya. Dukungan pemerintah AS terhadap Freeport sungguh sangat kuat, sehingga di Indonesia Freeport tidak banyak mendapat tekanan".

Jika PMA yang tujuannya untuk mempercepat pembangunan dan memberikan kesejahteraan rakyat juteru menyebabkan kedaulatannya tergadai, berarti PMA tersebut bermasalah. Jika masalahnya pada regulasi dan peraturan perundangan, maka perlu segera disusun regulasi dan peraturan baru yang mampu melindungi kedaulatan negara. Jika masalah ada pada pelaksanaan regulasi, maka pemerintah wajib segera mengevaluasi dan melaksanakan perbaikan-perbaikan menyeluruh.

\section{c. Kajian Terhadap Kontrak Karya Freeport}

$$
\text { Kendatipun usaha pemerintah }
$$
mengundang modal asing ini telah dilakukan dengan berbagai cara, namun belum mememberikan hasil yang menggembirakan. Jangankan untuk menambah, untuk mempertahankan yang sudah ada juga masih sulit. Sebagai contoh berhenti operasionalnya PT. Sony Elektronik Indonesia pada 
AL-IMARAH: Jurnal Pemerintahan dan Politik Islam Vol. 5, No. 1, 2020

Nopember 2002, yang disebabkan tekanan ekonomi global dan bisa jadi kondisi internal yang belum kondusif ${ }^{12}$.

Di satu sisi, keberadaan PMA tidak bisa ditunda lagi untuk melaksanakan pembangunan, di sisi lain dibutuhkan suatu kebijakan yang bisa menarik minat investor untuk berinvestasi di Indonesia . sesuatu yang dilematis bagi pemerintah Indonesia, sehingga lahir kebijakan yang sangat rawan bagi kedaulatan bangsa, yaitu membuat kontrak dengan masa yang sangat panjang, kepemilikan saham asing yang sangat besar hingga lebih dari $90 \%$ serta aturan divestasi yang sangat lamban. Hal ini akan merugikan bangsa baik secara ekonomi, politik dan sosial budaya. Dan diperparah dengan penegakan hukum yang sangat lemah, sehingga investor berani melakukan perlawanan hukum seperti yang terjadi pada PMA PT. Newmont Internasional di Propinsi Nusa Tenggara Timur, terkait dengan regulasi dan peraturan divestasi ${ }^{13}$ dan PT. Freeport di Papua ${ }^{14}$.

Dilema ini harus dijawab dengan kebijakan politik yang tepat. Sebab salah kebijakan akan berakibat larinya investasi asing, dan bisa jadi Indonesia akan kehilangan sebagian dari kedaulatannya. Sebenarnya jika rezim-rezim yang ada di Indonesia konsisten

12 Onti et.al. Tinjauan Atas Kebijakan Divestasi Saham Perusahaan PMA, HTML, www.lawskripsi, Oktober 2008.

${ }^{13}$ Onti.et.al

${ }^{14}$ Firdaus, Ilyas. Kontrak Karya PT. Freeport Indonesia. HTML, 2014

91 dengan lahirnya kebijakan PMA, dimana kebijakan diakukan pada bidang-bidang tertentuyang Indonesia belum mampu mandiri, seperti pertambangan, dimana kebijakannya adalah alih teknologi dan pemasukan modal. Contoh adalah kontrak karya antara pemerintah Indonesia dengan PT. Freeport Indonesia. Seharusnya waktu waktu satu kali 30 tahun masa kontrak karya yakni dari tahun 1967-1997 itu cukup untuk melakukan alih teknologi pertambangan, dan memperoleh divestasi sebesar 51\% sebagaimana regulasi divestasi yang disepakati kedua belah pihak, sehingga jika kontrak tersebut diperpanjangm saham mayoritas adalah milik pemerintah, sehingga bangsa kita tidak bisa didikte oleh investor asing tersebut ${ }^{15}$. Dan pada perpanjangan kontrak yang kedua pemerintah telah memiliki kewenangan yang lebih besar disebabkan menjadi pemegang saham mayoritas. Namun lagi-lagi rakyat tertipu, sebab kontrak karya dengan PT. Freeport tetap dilanjutkan dengan komposisi yang sama penguasaan saham, yakni Freeport pemegang saham mayoritas (90\% lebih), sedangkan Pemerintah Indonesia memiliki saham kurang dari $10 \%$ dan kontrak baru akan berakhir pada tahun 2021.

Sementara realitas di lapangan, investor (PT Freeport Indonesia) yang bergerak di bidang tambang emas dan tembaga di Papua, memiliki saham 90\% lebih

15 Onti et.al Tujuan atas kebijakan Divestasi Saham Perusahaan PMA 
sedangkan kepemilikan saham pemerintah kurang dari 10\%. Bahkan dalam substansi kontrak tersebut ada klausul yang menyatakan "yang mengikutinya" dari emas dan tembaga ${ }^{16}$, padahal disinyalir kaya potensi bouksit, biji besi, nikel dan uraniuma ada di lokasi eksplorasi tersebut. Artinya jika sinyalemen itu benar, maka potensi tersebut tidak masuk dalam klaususl kontrak yang harus bagi hasil kepemilikan yang kurang dari $10 \%$ tersebut.

Ironisnya pemerintah pada tanggal 24 April 2014 (7 tahun sebelum berakhirnya kontrak karya dengan PT Freeport), telah menandatangani perpanjangan kontrak karya yang ketiga hingga tahun 2045, dengan posisi kepemilikan sahan masih dibawah 10\%, kendatipun pemerintah mengklaim telah melakukan renegosiasi dan telah disepakati kedua belah pihak termasuk divestasi $30 \%^{17}$ dan nilai royalti emas $3,75 \%{ }^{18}$.

Kebijakan politik dan hukum ini akan berdampak secara signifikan terhadap kedaulatan politik, ekonomi, dan sosial budaya bangsa. Padahal seharusnya, jika pemerintah lebih berhati-hati, maka hasil dari bagi hasil di PT Freeport saja sudah lebih dari cukup untuk membiayai APBN setiap tahunnya, yang berarti negara ini akan surplus besa, karena potensi PNB dari bagi hasil perusahaan tambang yang lain masih sangat besar pula. Sehingga tidak ada defisit APBN dan tidak akan menekan ekonomi rakyat.

17 Wakil Menteri ESDM, Susilo Siswo Utomo, menyatakan negara harus mendapat keuntungan terbesar dari usaha pertambangan yang ada di Indonesia. Karena itu pemerintah tetap meminta Freeport untuk mendivestasikan 30\% sahamnya. "yang penting negara harus dapat bagian besar, tetapi perusahaan harus tetap jalan, karena pendapatan negara ini kan untuk pembangunan". Kata Susilo Siswo Utomo pada Senin, (14/4/2014), ia menyatakan perusahaan asal amerika ini belum menerima permintaan pemerintah tersebut. Meskipun demikian, Ia menyatakan tanda-tanda ke arah kesepakatan mulai kelihatan. "Negosiasi masih berjalan, tetapi arahnya sudah semakin baik" katanya. Sebagai gambaran pemerintah mewajibkan Freeport untuk mendivestasikan 30\% sahamnya . nilai ini lebih rendah dari aturan undang-undang yang sebelumnya dipatok sebesar $51 \%$. Alasannya areal pertambangannya berada di bawah tanah atau underground

${ }^{18}$ Liputan 6 SCTV.com, Jakarta, 25 Juli 2014 : "Choirul Tanjung, Menteri koordinator bidang perekonomian era SBYmenyebut, tuntasnya proyek renegosiasi seluruh perusahaan tambang khususnya Freeport Indonesia akan memberi keuntungan bagi Indonesia dari sisi royalti, bea keluar dan devisa ekspor. Royaltinya ekspor langsung berlaku royalti baru sebagaimana PP No. 9 dengan besaran antara 3,75 s.d. 4 $\%$. Setiap tahun naik dari $1 \%$ ke $3,75 \%$ lalu naik menjadi $4 \%$ untuk barang emas dan tembaga. Jadi yang kita terima jauh lebih besar dari yang kita terima sebelumnya", ujarnya. 
AL-IMARAH: Jurnal Pemerintahan dan Politik Islam Vol. 5, No. 1, 2020

Menurut Khalid Muhammad (koordinator institut hijau Indonesia dan pendiri jaringan advokasi tambang), Kontrak Karya antara Pemerintah dengan PT Freeport Indonesia harus diakhiri dengan alasan, ”ada praktek yang tidak benar dalam keluarnya kontrak karya Freeport, baik pada tahun 1967, perpanjangan kontrak karya pada tahun 1991 yang itu harus direnegosiasi secara penuh oleh pemerintah. Lebih lanjut, Khalid merinci kerugian yang harus ditanggung Indonesia ${ }^{19}$.

\section{d. Adakah Kekuatan Asing Bermain Dalam Kontrak Karya Freeport}

19 Pertama, kehadiran freeport di Papua menjadi trigger terjadinya perlawanan Kelik Kwalik, seorang guru yang marah kepada pemrintah dan freeport atas kehadiran di tanah Amugme tanpa proses konsultasi yang sejati dengan orang Amugme, yang kemudian menyebabkan Kelik Kwalik sempat memutus pipa konsentrat freeport, pada tahun 70-an. Itulah awal Kelik Kwalik melakukan perlawanan dan selanjutnya memicu perlawanan di Tanah Papua hingga saat ini. Keinginan anak-anak Papua untuk memisahkan diri dari Indonesia juga tak lepas dari praktek ketidakadilan yang terjadi di wilayah sekitar eksplorasi freeport. Itu dampak politik di tingkat lokal.

Freeport menjadi penyebab berubahnya haluan ekonomi Indonesia dari ekonomi konstitusi menjadi ekonomi liberal di masa Soeharto lewat UU PMA dan UU Pertambangan, di mana tangan-tangan Freeport bekerja.

Pemerintah menjadi takluk terhadap korporasi karena begitu banyak pelanggaran dilakukan oleh freeport tetapi tetap dapat pemaafan, dari pemerintah, atau bahkan dicari-cari alasan pembenar. Kemudian saat bergulirnya dana satu persen oleh freeport, justru menjadi pemicu konflik antar etnik yang terjadi di Papua.

Pelanggaran HAM begitu banyak terjadi di wilayah operasi Freeport sejak awal, tanpa ada tindakan hukum meskipun sudah diungkapkan melalui laporan seorang Belanda ke Komnas HAM yang menyebut adanya pelanggaran HAM. Laporan itu ditindak lanjuti oleh komnas HAM yang waktu itu ketuanya dijabat oleh Marzuki Darusman. Belakangan diketahui Marzuki diangkat menjadi Komisaris PT Freeport. 93
Untuk menjawab pertanyaan ini, penulis akan mengutip secara lengkap sebuah artikel yang ditulis oleh Lisa pause, yang diterbitkan oleh majalah Forbe dan disimpan di National Archive di Washington DC, berjudul "JFK, Indonesia, CIA and Freeport" sebagai berikut :

"Pada sekitar tahun 1961, Presiden Soekarno gencar merevisi kontrak pengelolaan minyak dan tambang-tambang asing di Indonesia, minimal sebanyak $60 \%$ dari keuntungan perusahaan minyak asing tersebut harus menjadi jatah rakyat Indonesia. Namun kebanyakan dari mereka gerah dengan peraturan ini. akhirnya skenario jahat para elit dunia mulai direncanakan terhadap kekayan alam dalam negeri tercinta Indonesia.

Pada akhir tahun 1996, sebuah artikel yang ditulis oleh Lisa Pease, yang dimuat dalam majalah Probe. Tulisan ini juga disimpan dalam judul tulisan tersebut, walau dominasi Freeportatas "Gunung Emas" di Papua sudah dimulai sejak tahun 1967, namun kiprahnya di negeri ini sudah dimulai beberapa tahun sebelumnya.

Pada kesempatan ini kami akan menguak sedikit dai banyaknya tandatanyatandatanya besar yang masih tersimpan di saku tiap rakyat Indonesia yang tercinta ini dan belum terjawab, bahkan tak akan pernah terjawab. Hal itu dilakukan karena pada masa rezim New Order atau ordebaru itu banyak sekali sejarah-sejarah yang tidak boleh 
dipublikasikan, ditulis ulang, dibengkokkan, lalu dipropagandakan melalui media-media zombieyang pada masa lalu bagai "Media Peliharaan". Dalam tulisannya isa Pease mendapatkan temuan jika Freeport Shulphur, demikian nama perusahaan itu awalnya, nyaris bangkrut berkeping-keping ketika terjadi pergantian kekuasaan di Kubapada tahun 1959. Saat itu di Kuba, Fidel Castro berhasil menghancurkan rezim diktator Batista. Oleh Castro seluruh perusahaan asing di negeri itu dinasionalisasikan. Freeport Shulphur yang baru saja hendak melakukan pengapalan nikel produksi perdananya dari Kuba, akhirnya terkena imbasnya. Maka terjadi ketegangan di Kuba.

Menurut Lisa Pease, berkali-kali CEO Freeport Sulphur merencanakan pembunyhan terhadap Fidel Castro, tetapi berkali-kali pula mengalami kegagalan. Ditengah situasi ketidak pastian, pada Agustus 1959, Forbes Wilson yang menjabat sebagai direktur Freeport Sulphur, melakukan pertemuan dengan direktur pelaksana East Borneo Company, Jan Van Gruisen. Dalam pertemuan itu Gruinsen bercerita jika dirinya menemukan sebuah laporan penelitian atas gunung Ersberg (gunung tembaga) di Irian Barat yang ditulis oleh Jean Jacques Dozy di tahun 1936. Forbes Wilson, direktur Freeport Sulphur 1959 (pi : mininghalloffame.org).

Uniknya laporan tersebut sudah dianggap tidak bergunadan terseimpan selama bertahun-tahun begitu saja di perpustakaan Belanda. Namun Van Gruisen tertarik dengan laporan penelitian yang sudah berdebu tersebut dan membacanya dengan berapi-api bercerita dengan pemimpin Freeport Sulphur itu juga memaparkan tentang keindahan alamnya dan kekyan alamnya yang begitu melimpah . tidak seperti wilayah lain di seluruh dunia, maka kandungan biji tembaga yang ada di sekujurtubuh gunung Ersberg itu terhampar di atas permukaan tanah, jadi tidak tersembunyi di dalam tanah. Mendengar hal itu Wilson sangat antusias dan segera melakukan perjalanan ke Irian Barat untuk mengecek kebenaran cerita itu.

Dalam benaknya jika laporan itu benar, maka perusahaannya akan bisa bangkit kembali dan selamat dari kebangkrutan yang sudah di depan mata. Selama beberapa bulan Forbes Wilson melakukan survey dengan seksama atas gunung Ersberg dan juga wilayah sekitarnya. Penelitian ini kelak ditulisnya dalam sebuah buku berjudul The Conguest of Cooper Mountain. Wilson menyebut gunung tersebut sebagai harta karun yang terbesar, yang untuk memperolehnya tidak perlu menyelam lagi, karena semua harta karun itu telah terhampar di permukaan tanah. Dari udara, tanah di sekujur gunung tersebut berkilauan ditimpa sinar matahari. Wilson juga mendapat temuan yang nyaris membuatnya gila, karena selain dipenuhi biji tembaga gunung tersebut juga dipenuhi biji emas dan perak. 
AL-IMARAH: Jurnal Pemerintahan dan Politik Islam Vol. 5, No. 1, 2020

Menurut Wilson seharusnya gunung tersebut diberi nama GOLD MOUNTAIN, bukan gunung tembaga. Sebagai seorang pakar pertambangan, Wilson memperkirakan jika freeport akan untung besar, hanya dalam waktu tiga tahun pasti sudah kembali modal. Pimpinan Freeport Sulphur inipun bergerak dengan cepat. Padatanggal 1 Februari 1960, Freeport Sulphur meneken kerjasama dengan East Borneo Company untuk menekplorasi gunung tersebut.

Namun lagi-lagi $\quad$ Freeport

Sulphurmengalami kenyataan yang hampir sama yang pernah dialaminya di Kuba. Perubahan ekskalasi politik atas tanah Irian Barat tengah mengancam. hubungan antara Indonesia tengah memanas dan Sukarno bahkan mulai menerjunkan pasukannya di Irian Barat. Tadinya Wilson ingin meminta bantuan kepada presiden AS John Fitzgerald Kennedy (JFK) agar mendinginkan Irian Barat. Namun ironisnya JFK malah mendukung Soekarno. Kennedy mengancam Belanda, akan meenghentikan bantuan Marshall Plan, jika ngotot mempertahankan Irian Barat. Belanda yang saat itu memerlukan bantuan dana segar untuk membangun negerinya dari puing-puing kehancuran akibat Perang Dunia II, terpaksa mengalah dan mundur dari Irian Barat. Ketika itu sepertinya Belanda tidak tahu jika gunung Ersberg sesungguhnya mengandung banyak emas, bukan tembaga.
Sebab jika saja Belanda mengetahui fakta sesungguhnya, maka nilai bantuan Marshall Plan yang diterimanya dari AS, tidak ada apa-apanya dibanding nilai emas yang ada di gunung tersebut. Dampak dari sikap Belanda yang mundur dari Irin Barat menyebabkan perjanjian Freeport Sulphur dengan East Borneo ompany batal. Para pemimpin Freeport marah besar dengan JFK. Apalagi mendengar JFK akan menyiapkan paket bantuan ekonomi kepada Indonesia sebesar 11 juta dolar AS dengan melibatkan IMF dan Bank Dunia. Semuanya ini jelas harus dihentikan! segalanya berobah 180 derajat ketika JFK tewas ditembak pada tanggal 22Nopember 1963.

Banyak kalangan mengatakan bahwa penembakan JFK merupakan sebuah konspirasi besar menyangkut kepentingan kaum globalis yang hendak mempertahankan hegemoninya atas kebijakan politik di AS. Presiden Jhonson yang menggantikan JFK, mengambil sikap yang bertolak belakang dengan pendahulunya. Johnson malah mengurangi bantuan ekonomi untuk Indonesia, kecuali kepada militernya. Salah seorang tokoh di belakang keberhasilan Johnson termasuk dalam kampanye pemilihan presiden AS tahun 1964 adalah Augustus C. Long, salah satu anggota dewan direksi Freeport. Tokoh satu ini memang punya kepentingan besar di Indonesia. Selain kaitanya dengan Freeport, Long juga memimpin Texaco yang membawahi Caltex (patungan dengan 
Standard Oil of California). Soekarno pada tahun 1961 memutuskan kebijakan baru kontrak perminyakan yang mengharuskan 60 $\%$ labanya diserahkan kepada pemerintah Indonesia.

Caltek sebagai salah satu dari tiga operator perminyakan di Indonesia jelas sangat terpukul oleh kebijakan Soekarno ini. Augustus C. Long amat marah kepada Soekarno ini dan amat berkepentingan agarorang ini disingkirkan secepatnya. Mungkin suatu kebetulan yang ajaib, Augustus C. Long juga aktif di Presbysterian Hospital di New York, di manadia pernah dua kali menjadi presidennya (1961-1962). Sudah bukan rahasia umum lagi bahwa tempat ini merupakan salah satu simpul pertemuan tokoh CIA. Lisa Pease dengan cermat menelusuri riwayat kehidupan tokoh ini, antara tahun 1964-1970. Long pensiun sementara sebagai pemimpin Texaco.

Apa saja yang dilakukan orang ini pada masa itu, yang di Indonesia dikenal sebagai "masa yang paling krusial" . pease mendapatkan data jika pada Maret 1965, Augustus C. Long terpilih sebagai direktur Chemical Bank, salah satu perusahaan Rockefeller. Pada bulan Agustus 1965, Long diangkat sebagai anggota dewan penasehat intelijen kepresidenan AS untuk masalah luar negeri. Badan ini mempunyai pengaruh sangat besar untuk menentukan operasi rahasia AS di negara-negara tertentu. Long diyakini sebagai salah satu tokoh yang merancang kudeta terhadap Soekarno, yang dilakukan AS dengan mengerahkan sejumlah perwira Angkatan Darat yang disebutnya sebgai Our Local Army Friend. Sedangkan menurut pengamat sejarawan Lembaga Ilmu Pengetahuan Indonesia (LIPI), DR. Asvi Marwan Adam, Soekarno benar-benar ingin sumber daya alam Indonesia dikelola oleh anak bangsa sendiri.

Asvi juga menuturkan, sebuah arsip di Kedutan Besar AS di Jakarta yang mengungkapkan pada tanggal 15 Desember 1965, sebuah tim yang dipimpin oleh Chaerul Saleh di istana Cipanas sedang membahas nasionalisasi perusahaan asing di Indonesia. Soeharto yang pro pemodal asing datang ke sana dengan menumpang helikopter. Dia menyatakan pada peserta rapat, bahw Dia dan Angkatan Darat tidak setuju rencana nasionalisasi perusahaan asing tersebut, "Soeharto sangat berani saat itu, Bung Karno juga tidak pernah memerintahkan seperti itu”, kata Asvi.

Sebelum tahun 1965 seorang Taipan dari Amerika Serikat menemui Soekarno. Pengusaha itu menyatakan keinginannya berinvestasi di Papua. Namun Soekarno menolak secara halus, "saya sepakat dan itu tawaran yang menarik, tapi tidak untuk saat ini, coba tawarkan untuk generasi setelah saya", Ujar Asvi menirukan jawaban Soekarno. Soekarno berencana modal asing baru akan masuk 20 tahun lagi, setelah putra- 
AL-IMARAH: Jurnal Pemerintahan dan Politik Islam Vol. 5, No. 1, 2020

putri Indonesia mampu mengelola. Dia tidak mau perusahaan luar negeri masuk, sedangkan Indonesia masih memiliki pengetahuan nol tentang alam mereka sendiri.

Oleh karenanya sebagai persiapan, Soekarno mengirim banyak mahasiswa belajar ke negara-negara lain. Soekarno boleh saja membuat tembok penghalang untuk asing dan mempersiapkan calon pengelola negara. Namun Asvi menjelaskan bahwa usaha pihak luaryang bernafsu ingin mendongkel kekuasaan Soekarno, tidak kalah kuat. Setahun sebelumnya yakni tahun 1964, seorang peneliti diberi akses untuk membuka dokumen penting Departemen Luar Negeri Pakistan di Eropa. Dalam surat per Desember 1964, diplomat itu menyampaikan informasi rahasia dari intel Belanda yang mengatakan dalam waktu dekat, Indonesia akan beralih ke Barat. Lisa menjelaskan maksud dari informasi itu adalah akan terjadi kudeta di Indonesia oleh Partai Komunis. Sebab itu Angkatan Darat mempunyai alasan kuat untuk menamatkan Partai Komunis Indonesia (PKI), setelah itu membuat Soekarno menjadi tahanan. Telegram rahasia dari Departemen Luar Negeri Aske Perserikatan Bangsa Bangsa (PBB) pada April 1965 menyebut bahwa Freeport Sulphur sudah sepakat dengan Pemerintah Indonesia untuk penambangan Puncak erstberg di Papua, salah satu bukti sebuah telegran rahasia Cinpac 342, 21 Januari 1965, pukul 21.48, yang menyatakan ada pertemuan para panglima tinggi dan pejabat 97
Angkatan Darat Indonesia yang membahas rencana darurat tersebut, bila Presiden Soekarno meninggal. Namun kelompok yang dipimpin oleh Soeharto ternyata bergerak lebih jauh dari rencana itu. Soeharto mendesak agar Angkatan Darat mengambil alih kekuasaan tanpa menunggu Soekarno berhalangan.

Mantan pejabat CIA Ralph Mc Gehee juga pernah bersaksi bahwa semuanya itu memang benar adanya. Maka dibuatlah PKI sebagai kambin hitam sebagai tersangka pembunuhan tujuh Dewan Jendral yang pro terhadap Soekarno melalui Gerakan Tiga Puluh September yang didalangi PKI atau dikenal oleh pro-Soeharto sebagai "G-30/SPKI", dan disebut juga Gestapu (gerakan Tigapuluh) Sepember oleh pro-Soekarno. Setelah pecahnya Gerakan 30 September 1965, keadaan negara Indonesia berubah total. Terjadi kudeta yang telah direncanakan dengan "memelintir dan mengubah" isi surat perintah sebelas maret(Supersemar) 1966, yang akhirnya isi dari surat perintah tersebut disalah-artikan. Dalam Supersemar, sebenarnya Soekarno hanya memberi mandat untuk mengatasi negara yang kacau balau kepada Soeharto, bukan justru menjadikannya sebagai seorang presiden. Pada awal Nopember 1965, satu bulan setelah terjadinya tragedi terbunuhnya sejumlah perwira loyalis Soekarno, Forbes Wilson mendapat telpon dari ketua dewan direksi Freeport Sulphur, Langbourne Williams, yang menanyakan, " Apakah Freeport sudah siap untuk 
mengeksplorasi gunung emas di Irian Barat ?". Forbes Wilson jelas kaget. Dengan jawaban dan sikap tegas Soekarno yang sudah tersebar dalam dunia para elit dan kartel pertambangan, Wilson tidak percaya dengan pertanyaan itu. Dia berpikir Freeport masih akan sulit mendapatkan izin, karena Soekarno masih berkuasa. Ketika itu Soekarno masih sah sebagai presiden Indonesia hingga tahun 1967. Lalu bagaimana Wilson yakin bahwa gunung emas di Irian Barat akan jatuh ke Freeport ? Lisa Pease mendapatkan jawabannya, para petinggi Freeport ternyata sudah memiliki kontak dengan tokoh penting di dalam lingkaran elit Indonesia.

Oleh karena itu, usaha Freeport untuk masuk ke Indonesia akan semakin mudah. Beberapa elit Indonesia yang dimaksud pada era itu diantaranya adalah menteri Pertambangan dan Perminyakan, Ibnu Sutowo. Namun pada saat penandatanganan kontrak dengan Freeport, dilakukan oleh menteri pertambangan Indonesia selanjutnya, yaitu Ir. Slamet Bratanata. Disamping itu juga ada bisnisman sekaligus makelar untuk perusahaan-perusahaan asing yaitu Julius Tahija, sebagai penghubung antara Ibnu Soetowo dengan Freeport. Dalam bisnis ia menjadi pelopor dalam keterlibatan pengusaha lokal dalam perusahaan multi nasional lainnya, antara lain terlibat dalam PT. Faroka, PT Procter \& Gambler (Inggris) PT. Filma, PT. Samodera Indonesia, Bank Niaga termasuk PT. Freeport Indonesia. Sedangkan Ibnu
Soetowo sendiri sangat berpengaruh di dalam Angkatan Darat, karena ialah yang menutup seluruh anggaran operasional mereka.

Sebagai bukti ialah dilakukannya pengesahan Undang Undang Penanaman Modal Asing (PMA) pada tahun 1967 yaitu UU No 1/1967 tentang Penanaman Modal Asing, yang draftnya di rancang di JenewaSwiss yang didiktekan oleh Rockefeller, seorang Bilderberger. Maka Freeport menjadi perusahaan asing pertama yang kontraknya ditandatangani oleh Soeharto. Bukan saja menjadi lembek, bahkan sejak detik itu, Indonesia menjadi negara yang sangat tergantung terhadap Amerika, hingga saat ini atau bahkan selamanya. bahkan beberapa bulan sebelumnya yaitu pada tanggal 28 Februari 1967, secara resmi pabrik bata yang terletak di Kalibata Jakarta, juga diserahkan kembali oleh pemerintah Indonesia kepada pemiliknya. Penandatangan pengembalian pabrik bata dilakukan pada tanggal 3 Maret 1967, padahal pabrik bata tersebut sudah dikuasai oleh pemerintah.

$$
\text { Jadi untuk apa dilakukan }
$$

pengembalian? Dibayar berapa pemerintah dengan pengembalian tersebut? Lalu kemana uangnya? jika hal ini terjadi pada masa sekarang, pasti sudah heboh dengan pemberitaan negatif tentang hal ini. Penandatanganan penyerahan kembali pabrik bata dilkukanoleh Drs. Barli Halim, pihak pemerintah dan Mr. Bata ESG Bach. Masih di 
AL-IMARAH: Jurnal Pemerintahan dan Politik Islam Vol. 5, No. 1, 2020

tahun 1967, penandatanganan perjanjian kerja antara pemerintah Indonesia dengan Freeport untuk mengeksplorasi gunung emas di Irian Jaya dilakukan pada tanggal 7 April 1967. Freeport diperkirakan menginvestasikan 75 hingga 100 juta US dollar dengan pemerintah diwakili oleh menteri pertambangan dan perminyakan, Ir. Slamet Bratanata dan Freeport oleh Robert C. Hills (Presiden Freeport Sulphur) dan Forbes K Wilson (Presiden Freeport Indonesia), anak perusahaan yang dibuat untuk kepentingan ini, dan disaksikan oleh duta besar AS, Marshall Green, dengan luas konsensi mencapai 10,908 hektar selama 30 tahun. Pada Desember 1972 pengapalan perdana 10.000 ton tembaga dengan tujuan Jepang. Dari penandatanganan kontrak inilah yang menjadi dasar penyusunan UU No. 11 tahun 1967 tentang pertambangan yang disahkan pad Desember 1967. Setelah itu juga ditandatangani kontrak eksplorasi nikel di Irian Jaya oleh PT. Pacific Nikel Indonesia dengan pemerintah RI yang dilakukan oleh E. Of Veelen (Koninklijke Hoogovens) dan Soemantri Brodjonegoro (Mentri Pertambangan selanjutnya) dan RD Ryan (U.S. Steel), namun perjanjian-perjanjian tersebut menurut penulis banyak terdapat keganjilan. contoh pengemblian pabrik bata, apakah rakyat Indonesia tidak bisa membuat seperangkat sandal dan sepatu? nampak konspirasi busuk yang telah dimainkan di sini. Kemudian perjanjian eksplorasi PT Freeport, apakah mereka benar-benar menambang tembaga? penulis sangat yakin mereka menambang emas namun di perjanjiannya menambang tembaga.

Kejanggalan lainnya adalah perjanjian dengan PT. Pacific Nickel, apakah mereka benar-benar menambang nikel? penulis yakin mereka menambang perak, tetapi dalam perjanjian mereka menambang nikel. Begitu seterusnya perjanjian-perjanjian eksploitasi tambang di Indonesia dilakukan secara tidak wajar, tidak adil, terus menerus hingga puluhan bahkan ratusan tahun ke depan. Kekayaan alam Indonesiapun di gadaikan, terjual, dirampok, dibawa kabur ke negaranegara pro zionis tanpa mensejahterakan rakyat puluhan tahun lamanya. "saya melihat seperti balas budi Indonesia ke Amerika Serikat karena telah membantu enghancurkan komunis, yang konon bantuannya itu dengan senjata", tutur Asvi Marwan Adam.

Untuk membangun konstruksi pertambangan emasnya itu, Freeport menggandeng Bechtel, perusahaan AS yang banyak mempekerjakan pentolan CIA. Direktur CIA John Mc Cone, memiliki saham di Bechtel, sedangkan mantan direktur CIA Richard Helms bekerja sebagai konsultan internasional di tahun 1978. Tahun 1980 Freeport menggandeng Mc Moran milik Jim Bob Moffet dn menjadi perusahaan raksasa dunia dengan laba lebih dari 1,5 milyar dolar AS per tahun. tahun 1996, seorang eksekutif freeport-Mc Moran, George A. Maley, menulis 


\section{Sirwanto \\ Kebijakan Penanaman Modal Asing (Pma) Dan Dampak Kedaulatan Bangsa}

sebuah buku berjudul "Grasberg", setebal 384 halaman dan memaparkan jika tambang emas di Irian Barat itu memiliki deposit terbesar di dunia, sedangkan untuk biji tembaganya menempati urutan ke tiga terbesar di dunia. Maley menulis, data 1995 menunjukkan jika di areal ini tersimpan cadangan biji tembaga sebesar 40,3 milyar dolar Asdn masih akan menguntungkan untuk 45 tahun ke depan. Ironisnya Maley dengan bangganya menulis jika biaya produksi tambang emas dan tembaga terbesar di dunia di dunia yang ada di Irian Barat merupakan yang termurah di dunia! Istilah kota tembagapura itu sebenarnya menyesatkan dan salah.

Seharusnya Emaspura. Karena gunung tersebut memang gunung emas dan tembaga terserak di permukaan tanah, maka Freeport tinggal memungutinya dan kemudian baru menggalinya dengan sangat mudah. Freeport sama sekali tidak mau kehilangan emasnya dan membangun pipa-pipa raksasa dan kuat dari tambang grasberg (Grasber Mine) atau tembaga pura sepanjang $100 \mathrm{~km}$. Langsung menuju laut Arafuru, di mana telah menunggu kapal-kapal besar yang akan mengangkut emas dan tembaga ke AS. Ini sungguh-sunggh perampokan besar yang direstui oleh pemerintah RI sampai sekarang.

Menurut kesaksian reporter $\mathrm{CNN}$ yang diizinkan meliput tambang emas Freeport dari udara, dengan helikopter ia meliput tambang emas tersebut tahun 1990-an sudah berubah menjadi lembah yang dalam. Semua emas, perak dan tembaga yang ada di gunung tersebut sudah dibawa kabur ke Amerika, meninggalkan limbah beracun yang mencemari sungai-sungai tanah Papua hingga ratusan tahun ke depan. Menurut penelitian Greenpeace, operasi Freeport-Mc Moran di Papua telah membuang lebih dari 200.000 ton tailing per harinyake sungai Otomina dan Aikwa, yang kemudian mengalir ke laut Arafura. Dan hingga tahun 2006 lalu, diperkirakan telah membuang 3 miliar ton tailing yang sebagian besar berakhir di lautan. Sedimentasi laut dari limbah pertambangan hanyalah satu dari berbagai ancaman yang merusak masa depan lautan Indonesia.

Freeport juga menjadi ladang uang haram bagi para pejabat negeri ini di era Soeharto, baik sipil maupun militer, yang menjadikan freeport sebagai tambang untuk kepentingan pribadi mereka untuk memperkaya diri dan keluarganya. Freeport Mc Moran sendiri telah menganggarkan dana untuk itu, yang walaupun jumlahnya sangat besar bagi kita, namun bagi mereka teramat kecil, karena laba dari tambang tersebut sangat dahsyat. Jika Indonesia mau mandiri, maka sektor inilah yang harus di bereskan terlebih dahulu. Ini pula yang menjadi salah satu sebab siapapun yang menjadi presiden RI kedepannya, tak akan pernah mampu utuk mengubah perjanjian dan keadaan ini, karena jika presiden Indonesia berani mengutak utik tambang-tambang para elite dunia, maka 
AL-IMARAH: Jurnal Pemerintahan dan Politik Islam Vol. 5, No. 1, 2020

mereka akan mengunakan seluruh kekuatan politik, media dan militernya dan menggoyang kekuasaannya. Kerusuhan, adu domba, agen rahasia, mata-mata akan disebar ke seluruh pelosok negeri untuk menghasut dan membuat kekacauan yang menyebabkan hilangnya rasa aman dan ketidak puasan yang berujung pada penjatuhan kekuasaan. Inilah lingkaran setan yang diciptakn orde baru dn diwariskan kepada masyarakat indonesia ke depan. Kekayaan alam dari dasar laut, dalam bumi dan puncak gunung telah terjual. Bangsa besar yang kaya raya ini akhirnya menjadi bangsa yang kerdil yang dihantui dengan kemiskinan dan kelaparan berkepanjangan. Dan ini bukan konspirasi teori tetapi merupakan teori fakta yang harus dipahami oleh seluruh rakyat.

\section{e. Posisioning Indonesia Dalam Kontrak} Karya

Dari fakta yang diungkapkan Lisa Pease di atas, bahwa munculnya kebijkan dan aturan perundangan PMA bukanlah murni political will dari rezim yang berkuasa, tetapi juga intervensi dan tekanan politik dari elite dunia untuk merebut kedaulatan bangsa di berbagai bidang, dengan memanfaatkan pemimpin-pemimpin yang bisa dikendalikan oleh misi kapitalisme. Fakta di atas menggambarkan betapa lemah posisioning Indonesia dalam konteks pengambilan hak, sehingga negara dirugikan ratusan bahkan ribuan trilyun rupiah pertahun.
Undang-undang yang memerintahkan divestasi hingga $51 \%$ dan royalti penjualan dari hasil eksplorasi yang sudah ditetapkan oleh Undang-Undangsebesar 3,75 hingga 4\% per kilogram, tidak bisa direalisasikan setelah kontrak karya berjalan lebih dari empat dasawarsa. Ini adalah pelecehan terhadap kedaulatan RI yang embuat hati semakin miris. Permaalahannya bukan semata-mata masalah ekonomi, tetapi juga harga diri bangsa, pengkhiyanatan terhadap rakyat dan negara serta penjajahan secara struktural, meski kemerdekaan telah diproklamasikan 74 tahun yang lalu. Dan yang jelas posisioning pemerintah yang merupakan representasi rakyat Indonesia sebagai pemilik sah tanah laut dan udara Indonesia ini sangat lemah terhadap dominasi asing di berbagai bidang .

\section{Kesimpulan Dan Rekomendasi}

Dari pemaparan di atas, penulis mngambil kesimpulan bahwa fakta telah menunjukkan bahwa :

1. Kebijakan PMA memang ada keuntungan dan kerugiannya, tetapi keuntungan yang diperoleh negara dan rakyat terlalu kecil jika dibanding kerugian yang bersifat sistemik. Dan untuk mencegah dari kerugian itu dibutuhkan modal yang jauh lebih besar baik SDM, tekanan sosial politik, ekonomi, militer dan kerusakan lingkungan, apalagi untuk mengembalikan 
kerugian yang diderita berpuluh tahun.

2. Apakah kesalahan regulasi ? jika dilihat dari tahapan dan putusa peraturan perundang-undangan, tidak ada yang salah dari regulasi yang ditetapkan pemerintah. Dan jika regulasi ini diterapkan secara konsisten, dan pelanggaran yang terjadi segera ditindak sesuai peraturan, maka kerugian kalaupun terjadi tidak akan fatal dan bisa ditutupi dengan keuntungan yang diperoleh

3. Apakah ada kesalahan implementasi dari regulasi ? Penyebab kerugian negara, pada umumnya karena pemerintah tidak konsisten dengan peraturan yang dibuatnya. Sering kali memberi maklum terhadap kesalahan dan kecurangan mitra, padahal satu kesalahan yang dibuat akan melukai jutaan rakyat. contoh terkait dengan Divestasi dalam undang-undang yang $51 \%$, setelah lebih empat puluh tahun berlangsung implementasinya kurang dari $10 \%$, begitu juga dengan royalty penjualan yang seharusnya 3,75-4 \% per $\mathrm{kg}$, hanya diberikan kurang dari $1 \%$ dan pemerintah memaklumi karena pertambangan di bawah tanah, dan itu tidak masuk klausulkontrak.

4. Apakah ada intervensi asing yang mempengaruhi kebijakan PMA ? dari fakta yang terungkap ada intervensi Amerika melalui CIA, untuk menguasai tambang dan kekayaan negar, siapa yang menghalangi akan disingkirkan , baik dibunuh atau diturunkan dari jabatannya melalui operasi politik, operasi intelijen yang melibatkan kekuatan media, militer dan matamata dengan memanfaatkan orangorang yang tidak memiliki nasionalisme.

\section{Pustaka Acuan}

Salim, HS, Perkembangan Teori dalam Hukum, Raja Grafika Persada, Cet. Ke2; 2012.

Alfitri, Ideologi Walfare State Dalam Dasar Negara Indonesia, (Jurnal Konstitusi: Volume 9, No 3, September 2012).

Onti.et.al, Divestasi Saham dan Penanaman Modal Aing, www.lawskripsi.com; 2008.

Firdaus Ilyas, Kontrak Karya PT Freeport Indonesia, HTML, 2014.

Regulasi Penanaman Modal Asing; www.goegle.com, 2014.

Enam Poin Kesepakatan Renegosiasi Kontrak Karya dengan Freeport, www.goegle.com; download 4 Maret 2014.

Kwik Kian Gie, Forum Diskusi terkait dengan Bahan Bakar Minyak (BBM), download 3 Nov 2014. 
AL-IMARAH: Jurnal Pemerintahan dan Politik Islam

Vol. 5, No. 1, 2020

Liputan.6.com, Penjelasan Chairul Tanjung , Menko Perekonomian, terkait Renegosiasi PT Freeport Indonesia, 25 Juli 2014.

Seruu.com, Paparan Isi Kewajiban Bangun Smelter dalam Kontrak Freeport, (Jakarta: Senin, 1 April 2013).

Forum Keadilan, Wawancara dengan Khalid Muhammad (Koordinator Institut Hijau Indonesia, Pendiri Jaringan Advokasi Tambang) edisi 06/27 Mei-2 Juni 2013.

Akhmad Nurismarsyah, Kontrak Karya Tambang Emas Freeport, Jauh dari Kata Adil, detik finance .com; Selasa, 27/09/2011.

Rahadian, Salinan Kontrak Kerja sama antara pemerintah dengan Indonesia sebagai informasi terbuka, http://www.komisi informasi.go.id, 29 Mei 2013.

Lisa Pease, JFK, Indonesia, CIA and Freeport; article, Probe Magazine, Washington DC, 1996.

Basariyadi, Pergulatan Paham Negara Kesejahteraan, (Jurnal Hukum Ius Quia Lustum Volume 23 No. 4 Oktober 2016).

Putusan Mahkamah Konstitusi Nomor 001021-022/PUU-I/2003 tentang Pengujian UU Nomor 20 Tahun 2002 tentang Ketenagalistrikan terhadap UUD 1945.

Putusan Mahkamah Konstitusi Nomor 002/PUU-I/2003 tentang Pengujian UU Nomor 22 Tahun 2001 Minyak dan Gas Bumi. 